\title{
The Services Content of Japanese Trade
}

This paper investigates the share of direct and indirect services trade in Japanese trade between 1985 and 1995, using data from Japanese input-output tables. The empirical analysis reveals that the share of $R \& D$ services in total services trade has been much higher throughout the period than the share of other services. The contribution of school education services gradually increased from 1985 to 1995, while that of financial services declined. These results indicate that Japan increasingly exported technology-intensive products during the period, moving away from goods intensive in financial services to those intensive in educational services. After the bubble economy burst, exports of financial services declined and Japanese banking and insurance companies rapidly withdrew from overseas markets. Financial firms in Japan lack international competitiveness. Although structural reforms have been under way in some services sectors, the analysis in this paper suggests that greater reform is needed, especially in the financial sector.

\section{Introduction}

The expansion in world trade in services has been a major topic for research in recent years. Cross-country regression analyses have confirmed that the traditional Heckscher-OhlinVanek (HOV) Theorem has some validity in explaining patterns of services trade in that countries abundant in labour, or in physical capital or human capital, tend to export services that are intensive in that factor. ${ }^{1}$ However, the evidence has been weaker than the evidence on goods trade, suggesting a more detailed analysis of services trade is needed.

One possible reason for the weak application of the HOV theorem to services trade is that most services are traded indirectly, in that they are embodied in goods trade. Services are intangible and non-storable, ${ }^{2}$ and although technological change has enabled more services to be traded directly, most are used as intermediate inputs to produce goods. For instance, Japanese graduate students consume US research and educational services through imports of US books, but such imports are reported entirely as goods trade rather than services trade. Another example is when developing countries import machinery from industrialised countries, as various technical services such as research and development (R\&D) are embodied in the machinery. Studies of the services embodied in goods trade are therefore useful to shed light on the true trade in services. 


\section{Pacific Economic Papers}

There have been a large number of studies into the factor content of trade but only a few have analysed the services embodied in goods trade. Tucker and Sundberg (1988) examined the trade of Singapore in 1973, and Australia and Thailand in 1975. Their results indicated that the half of Australian services exports were embodied in goods exports, but that the embodied services exports of Thailand and Singapore were relatively small. Grubel (1988) looked at Canadian services trade between 1973 and 1983, finding that embodied services trade rapidly increased in that period and that the net surplus (exports minus imports) of indirect services trade was larger than the deficit of direct services trade in 1983.

Sazanami and Urata (1990) came up with similar findings when analysing Japanese and US indirect services trade, estimating that in both countries indirect services trade was so large that the total of direct and indirect services trade was in net surplus. Recent analysis by Urata and Kiyota (2001) extended the framework to six East Asian countries. The results suggested that industrialised countries with large services sectors are net exporters of services via goods trade.

These previous studies have confirmed that the services trade embodied in goods trade is significant for Japan and other countries. This paper expands the analysis by investigating direct and indirect services trade (the services content of Japanese trade) between 1985 and 1995 using input-output tables from Japan's Management and Coordination Agency. The detailed industrial classification (52 service industries out of a total 184 industries) allows for an empirical analysis of the input-output structure of services production and trade. The empirical analysis reveals that the share of $R \& D$ services in the total services content of trade is much higher than the share of other services. The share of school education services gradually increased from 1985 to 1995, while the share of financial services decreased rapidly. These results indicate that Japan exported technology-intensive products throughout the period. The pattern of Japanese exports dramatically changed between 1985 and 1995 from exports of goods intensive in financial services to those intensive in education services. The recent decline in the international competitiveness of the financial sector has been behind the falling share of financial services in services trade and the exit of Japanese banking and insurance companies from abroad. Structural reform in some services sectors in Japan is under way and the results suggest greater reform is needed, particularly in the financial sector.

\section{The model}

Owing to the difficulty in obtaining stock data, flow data from Japanese input-output tables for 1985, 1990 and 1995 are used for computing direct and indirect services trade. Suppose that 
services industries are indexed as $k+1, \ldots, \mathrm{l}$. Industry $\mathrm{i}$ is in the goods sector (agriculture, manufacturing, etc.) if $\mathrm{i} \leq \mathrm{k}$ and in the services sector if $\mathrm{i} \geq \mathrm{k}+1$. Let $S_{t i}^{h}(t \in\{x, m\})$ be the total (direct plus indirect) trade of service $i$ in country $h$, where $x$ and $m$ are exports and imports, respectively. $S_{t i}^{D h}$ and $S_{t i}^{I D h}$ represent the direct and indirect trade of service i in country h, respectively, and $S_{t i}^{h}=S_{t i}^{D h}+S_{t i}^{I D h}$.

Let $\mathbf{S}_{t}^{D h}$ and $\mathbf{S}_{t}^{I D h}$ be the vectors of direct and indirect services, respectively, in country h. Denote the trade vector in country $\mathrm{h}$ as $\mathbf{T}^{h}(\mathbf{T} \in\{\mathbf{E X}, \mathbf{I M}\})$, where $\mathbf{E X}$ and $\mathbf{I M}$ represent export and import vectors, respectively.

$$
\mathbf{S}_{t}^{h}=\mathbf{S}_{t}^{D h}+\mathbf{S}_{t}^{I D h}=\hat{\alpha} \mathbf{T}^{h}+\hat{\alpha} \mathbf{B}^{h} \cdot \hat{\beta} \mathbf{T}^{h}
$$

where $\hat{\alpha}$ is a diagonal matrix of $\alpha$, which takes the value of 1 if $i \geq k+1$ and 0 if $i \leq k$; and $\hat{\beta}$ is a diagonal matrix of $\beta$, which takes value of 1 if $i \leq k$ and 0 if $i \geq k+1$. $\mathbf{B}$ is a Leontief-inverse matrix. This paper calculates the services content of trade as net exports of direct and indirect services, similar to the calculation of the factor content of trade suggested by Leamer (1980) and Maskus (1985):

$$
\mathbf{S}_{x}^{h}-\mathbf{S}_{m}^{h}=\left(\hat{\alpha} \mathbf{E} \mathbf{X}^{h}+\hat{\alpha} \mathbf{B}^{h} \cdot \hat{\beta} \mathbf{E} \mathbf{X}^{h}\right)-\left(\hat{\alpha} \mathbf{I} \mathbf{M}^{h}+\hat{\alpha} \mathbf{B}^{h} \cdot \hat{\beta} \mathbf{I} \mathbf{M}^{h}\right)
$$

Denote the vector of services output in country h as $\hat{\mathbf{S}}^{h}$. Let $\left(\hat{\mathbf{S}}^{h}\right)^{-1}$ be the diagonal matrix whose elements are the inverse of services output $1 / S_{i}^{h}$. The content of a particular service in services trade can be estimated by presuming that its share of services trade is the same as its share of Japanese domestic output: ${ }^{3}$

$$
\left(\hat{\mathbf{S}}^{h}\right)^{-1}\left[\mathbf{S}_{x}^{h}-\mathbf{S}_{m}^{h}\right]=\left(\hat{\mathbf{S}}^{h}\right)^{-1}\left[\left(\hat{\alpha} \mathbf{E} \mathbf{X}^{h}+\hat{\alpha} \mathbf{B}^{h} \cdot \hat{\beta} \mathbf{E} \mathbf{X}^{h}\right)-\left(\hat{\alpha} \mathbf{I} \mathbf{M}^{h}+\hat{\alpha} \mathbf{B}^{h} \cdot \hat{\beta} \mathbf{I} \mathbf{M}^{h}\right](2)\right.
$$

Compute the ranking of services in the services content of trade. Equation (3) is modified as:

$$
\left.\left(S_{x i}^{h}-S_{m i}^{h}\right) / S_{i}^{h}\right\rangle\left(S_{x j}^{h}-S_{m j}^{h}\right) / S_{j}^{h}
$$

Therefore, 


$$
\left.\left(\left(S_{x i}^{D h}+S_{x i}^{I D h}\right)+\left(S_{m i}^{D h}+S_{m i}^{I D h}\right)\right) / S_{i}^{h}\right\rangle\left(\left(S_{x j}^{D h}+S_{x j}^{I D h}\right)+\left(S_{m j}^{D h}+S_{m j}^{I D h}\right)\right) / S_{j}^{h}
$$

Equation (3) indicates that service $i$ is more intensively used in the net exports of country $h$ than service $j$.

In contrast with factor content analysis, the analysis of services content will not necessarily reflect the abundance of particular services used in the domestic economy since some services are used in the production of other non-tradable services. ${ }^{4}$ The rank indicates the intensity of services used in trade, and partly the international competitiveness of services, but not the abundance of services.

\section{Data description}

The data used in the analysis come from the input-output tables published by the Management and Coordination Agency (2000) for the years 1985, 1990 and 1995. The industrial classification is constant over the period and prices are indexed, which allows a reliable time-series analysis to be performed.

The definition and sectoral coverage of trade in services in the input-output tables differ slightly from those used in the International Monetary Fund's Balance of Payments Statistics and by the World Trade Organisation. For instance, the tables do not include licence fees or distinguish services provided or purchased by foreign affiliates in Japan from those provided or purchased by Japanese domestic companies.

The values are converted from Japanese yen to US dollars using exchange rate data published by the IMF (2001). Although the input-output tables cover more than 500 industries, more aggregated data (for 184 industries including 52 services industries) is used so as to simplify the analysis.

Table 1 describes output and value added in Japan's services sector between 1985 and 1995, and Table 2 shows the trade in services. The share of each service industry's domestic production, value added and trade relative to the services total is reported in Table 3 . These tables confirm that domestic production, value added and trade rapidly expanded between 1985 and 1995 in the services sector. The average annual growth rates of production, value added, exports and imports in services were, respectively, 15.0 per cent, 14.5 per cent, 7.8 per cent and 10.7 per cent in the 1985-90 period; and 10.8 per cent, 10.8 per cent, 21.7 per cent and 10.0 per cent between 1990 and 1995. Compared with annual average growth of GDP over the 
same period (4.5 per cent in 1985-90 and 1.4 per cent in 1990-95), the growth rates of production, value added and trade in services were extremely high. ${ }^{5}$

An examination of the share of each services sector in the total shows some interesting differences between domestic production and trade. ${ }^{6}$ Over the period R\&D services were consistently around 1.5 per cent of both services production and value added, but appeared to be insignificant in services trade. Wholesale and retail services contributed the most to services output between 1985 and 1995. In 1995 wholesale services made up 10.7 per cent of services production and 11.7 per cent of value added, while retail services contributed 6.6 per cent to production and 7.4 per cent to value added. The shares of house rentals, construction and medical services were also high. The pattern of trade in these services varied significantly. While the wholesale sector contributed 34.7 per cent to services exports, retail services were only 0.2 per cent of services exports. Transport-related services such as ocean transport and air transport had relatively high shares. Financial services were also significant at 4.7 per cent of production in 1995, and 4.9 per cent of value added, and were also significant in trade at 5.6 per cent of services exports and 9.4 per cent of imports.

The ratio of net exports (exports minus imports) to total trade (exports plus imports) in services was quite high in 1985 (0.32) but around zero in $1990(-0.01)$ and $1995(0.00)$. The net export ratio of financial services was negative throughout the period and the net export ratio of insurance services gradually decreased. These results imply that Japanese services industries lost international competitiveness between 1985 and 1995.

\section{Services likely to be significant in services trade}

Research by Coe, Helpman and colleagues (Coe and Helpman 1995; Coe, Helpman and Hoffmaister 1997; Bayoumi, Coe and Helpman 1999) has suggested that OECD countries export R\&D services thorough goods trade. Since most of the Japanese current account surplus is from machinery exports, this suggests that Japan exports services that are intensive in R\&D services and therefore that the ranking or intensity of $R \& D$ services in the total services content is likely to be high.

Japan has a large financial services sector. Over the period Japanese financial services lost international competitiveness, and the net exports of the financial sector rapidly declined. A recent report (Toyokeizai 2001) described the exit of Japanese financial subsidiaries from overseas, and the fall in new entrants. The intensity of financial services in the services content of trade is therefore expected to have decreased between 1985 and 1995. 
Pacific Economic Papers

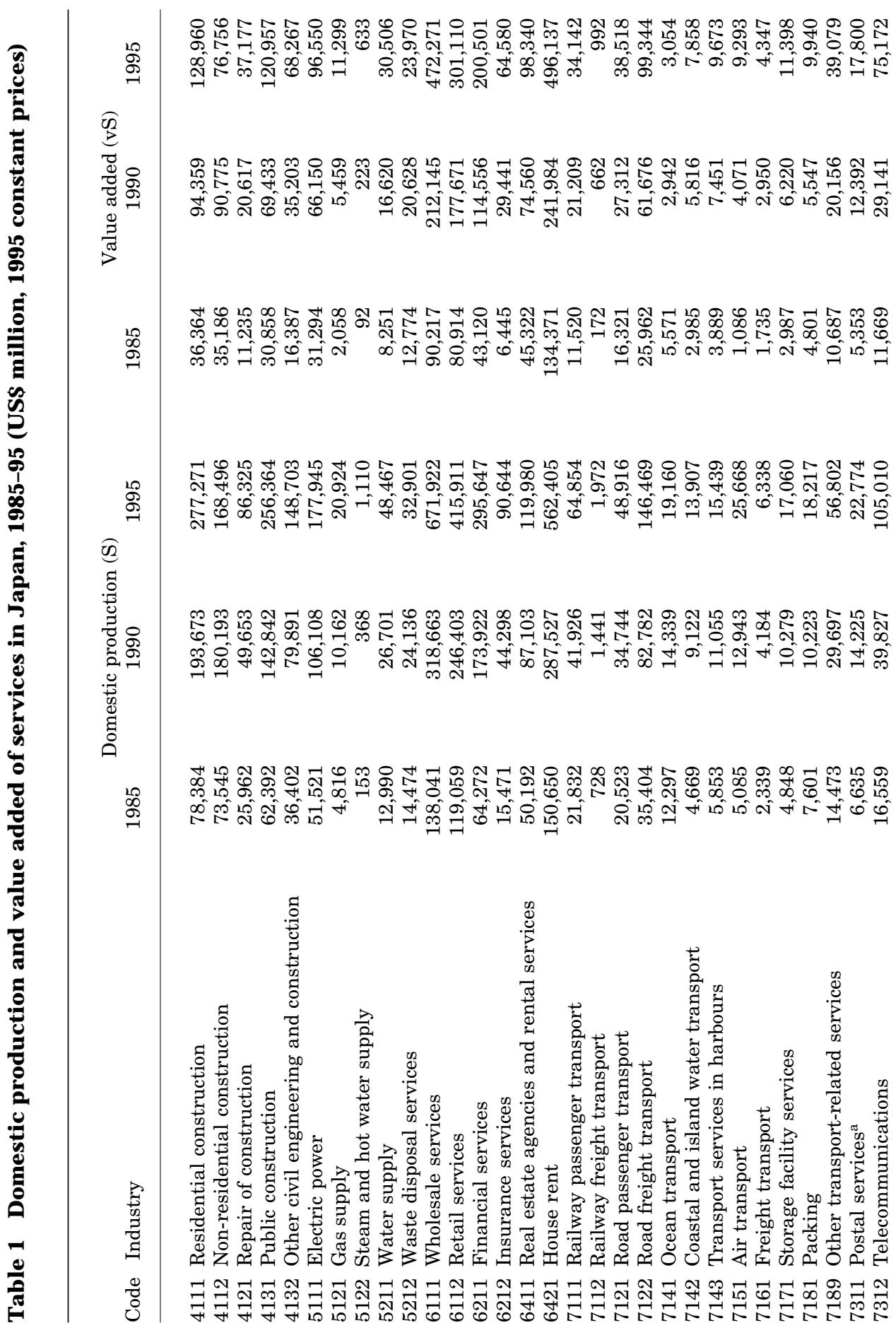


No. 320 O ctober 2001

주유. คै

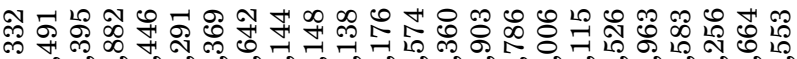

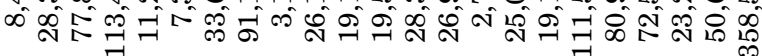

压视

$\sum_{i}$

兘

호론

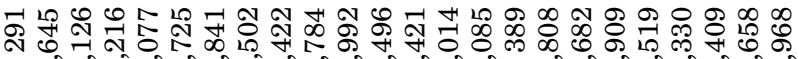

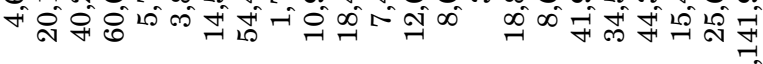

送

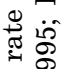

마에

๙

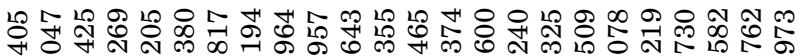

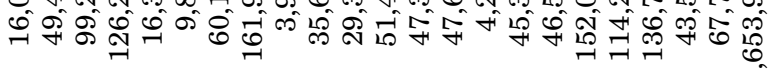

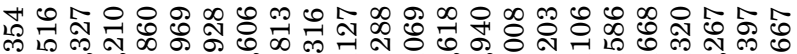

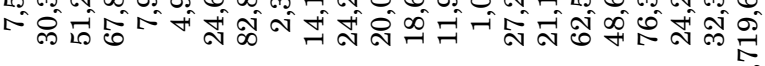

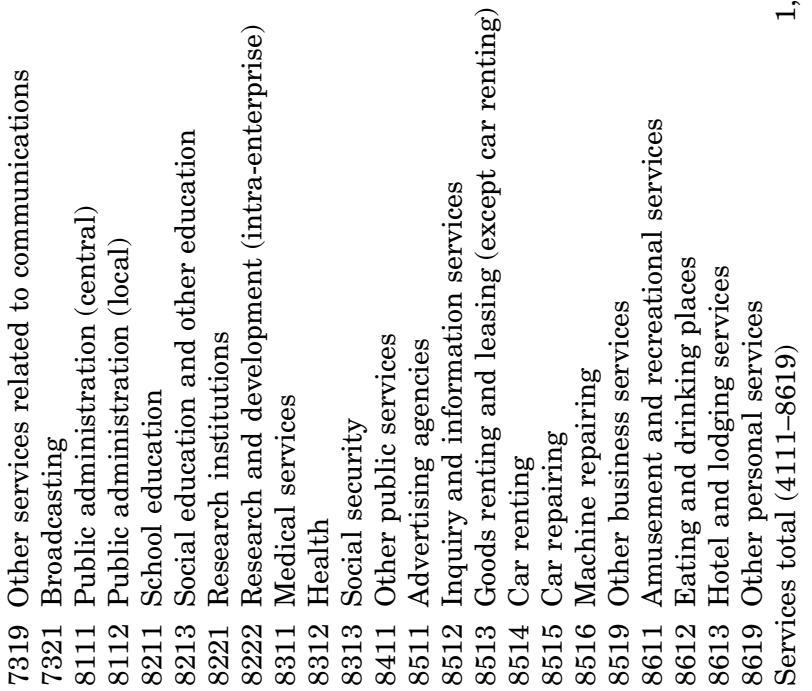

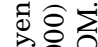

ن 우

究

空离

ह :

象遂

蛇

这

ठ० $\frac{\mathrm{C}}{\mathrm{T}}$

สี สี : $: \frac{5}{4}$

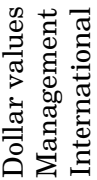

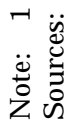


Pacific Economic Papers

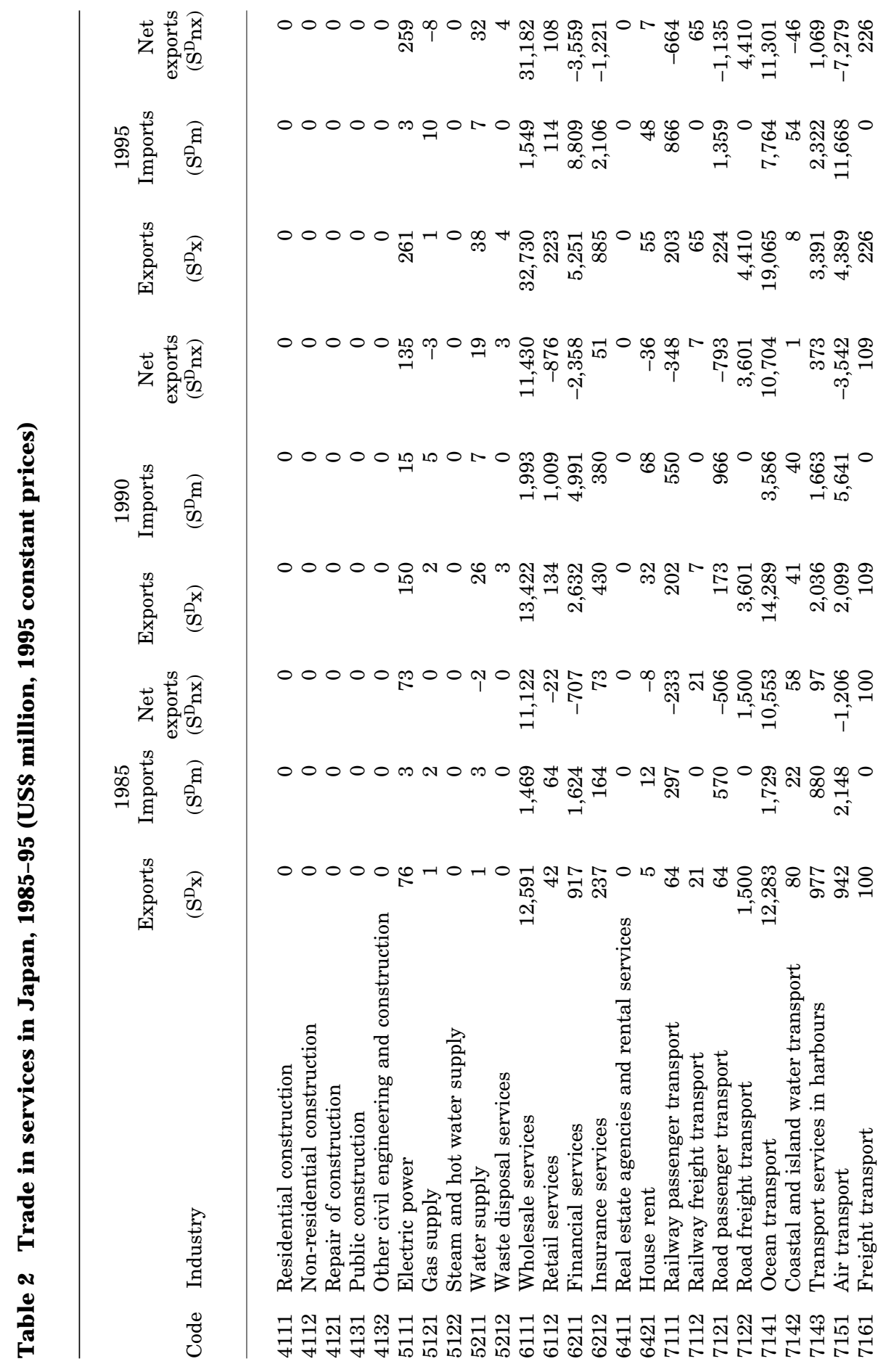




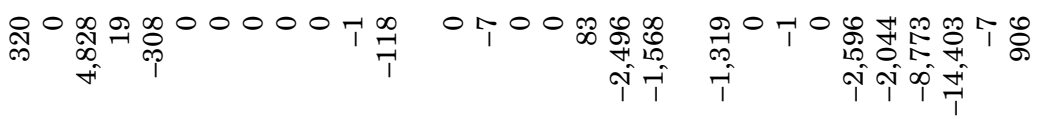

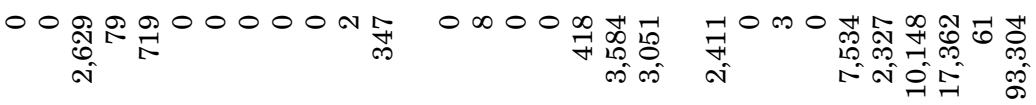

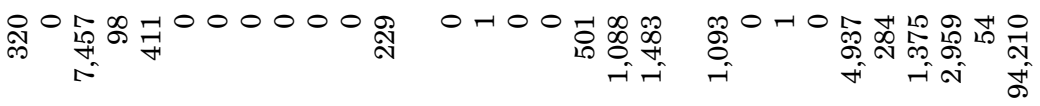

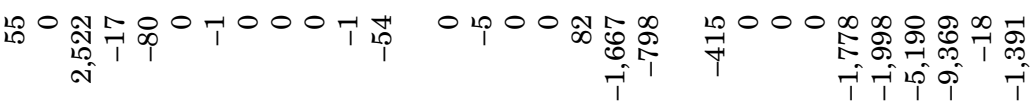

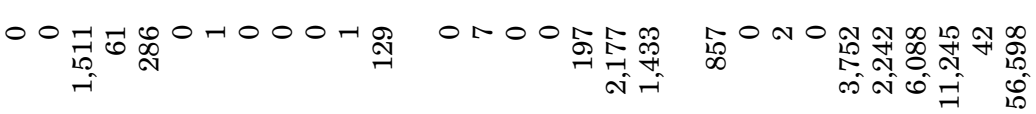

$$
\begin{aligned}
& \text { 100 }
\end{aligned}
$$

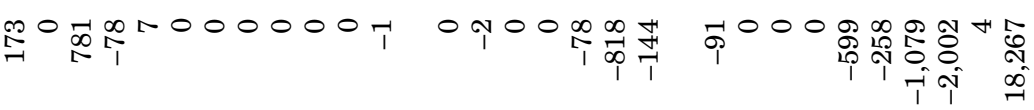

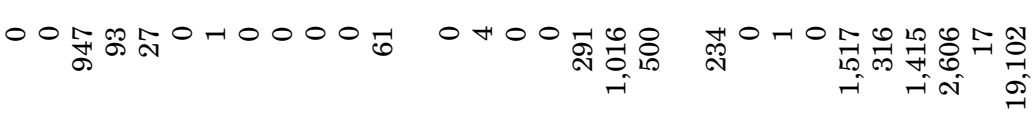

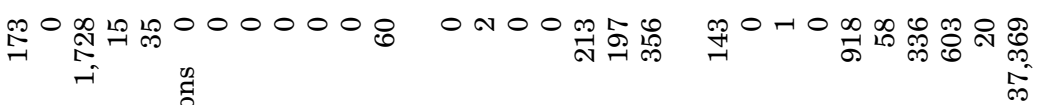

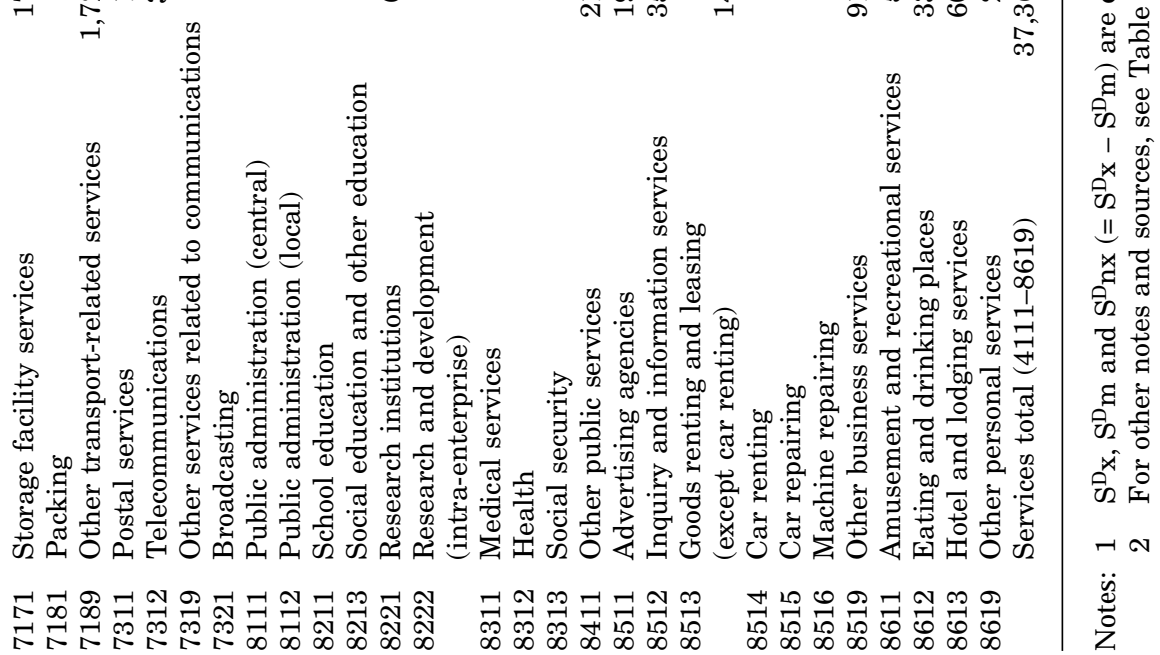




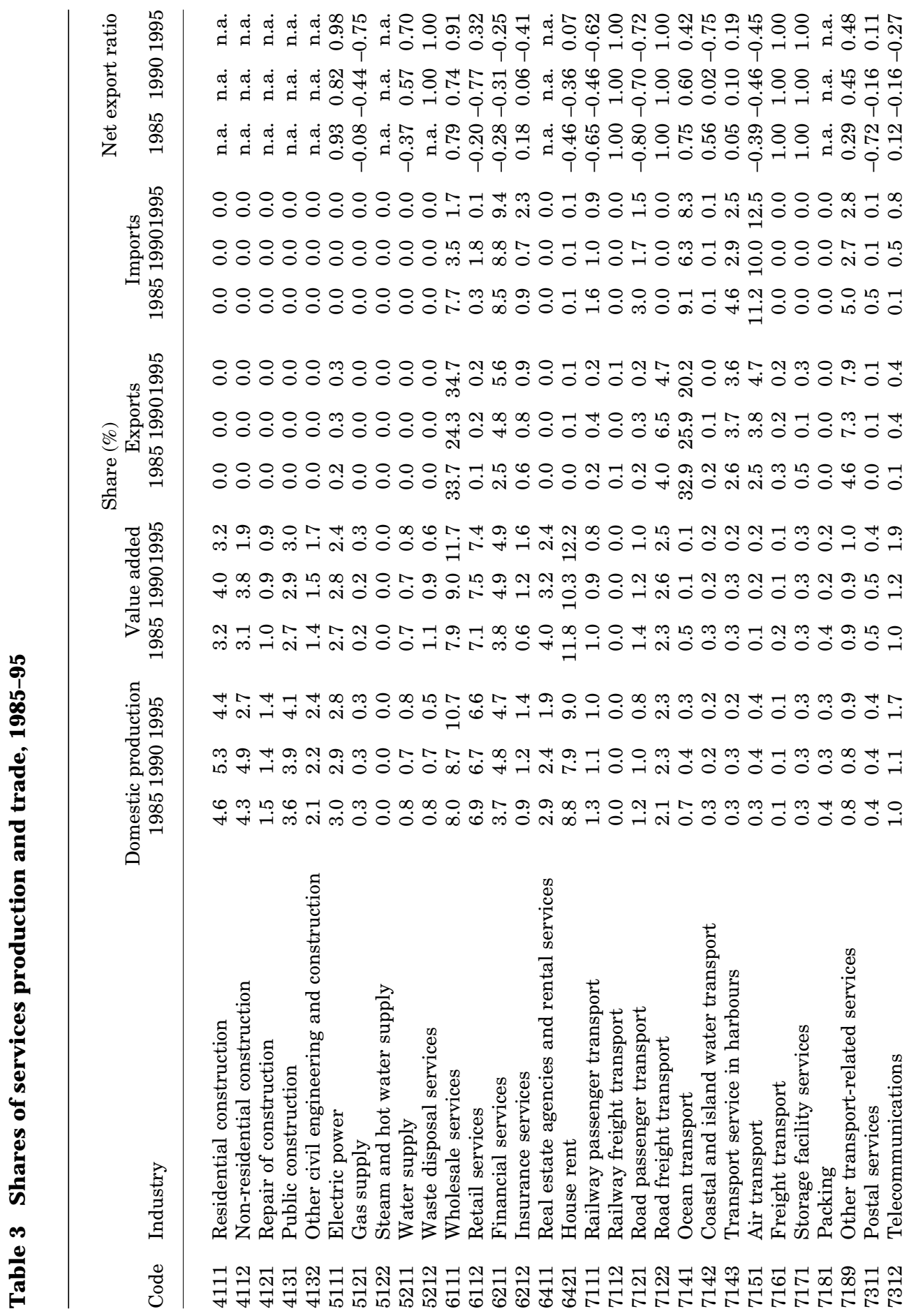


No. 320 O ctober 2001

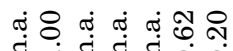
च ه્่ 요 द

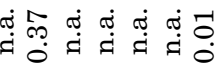

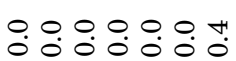

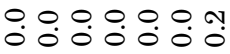

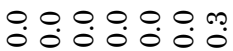

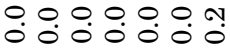

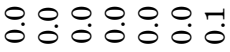

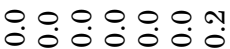
0. o. ○े $0.7 \infty 10 \mathrm{~m} \mathrm{~m} 10$ ن

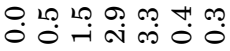

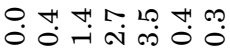
$0 .+\infty \circ 0.0 \%$ $\ddot{0}$
๔ِ ل ชื

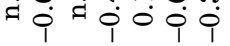
ชุ ณึ هึ่ व

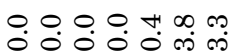
우웅 m 10

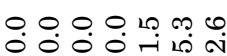

우웅ํ.

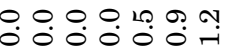

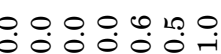

ฉ भi० 苞

$\infty \infty \times 00$ Hં

نَّ

b. H サִ œ $\infty$ ๓

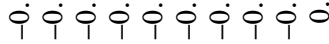
ผื 

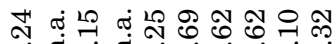
○े ஸ 1 L 10 0

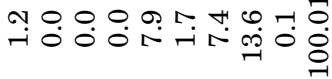
ำ

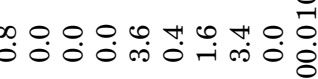
H. Ti்

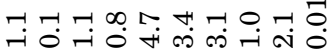

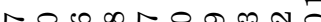

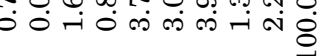

O N N ชน - - 6 N 0 a H $\dot{0} \dot{0} \dot{-1}$ ஸे

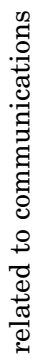
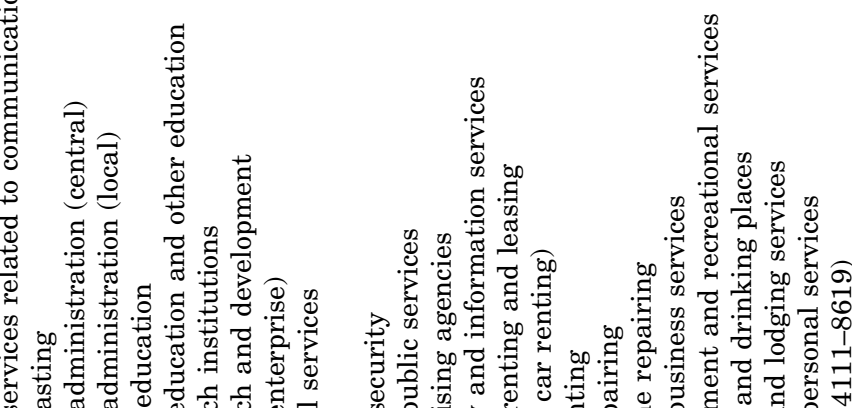

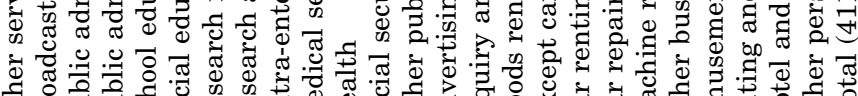

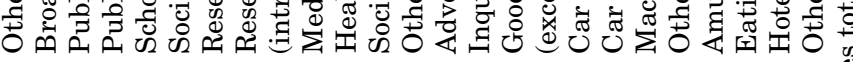

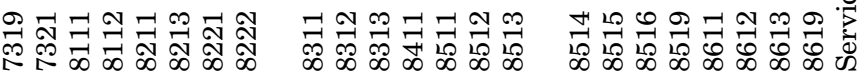


Traditional HOV regression analysis by Urata (1983) and Kimura and Kohama (1995) revealed that Japan exports goods that are human-capital intensive. This in turn implies that Japan exports educational services through goods trade and that the ranking of school education is likely to be high.

As Deardorff (1985) suggests, transportation services are also likely to be important in goods trade since transportation is required for the international trade in goods. Because Japan is an island country and a net exporter, the services content of air and ocean transportation services is likely to be high.

Japan economic structure and recent research on services trade therefore suggest that four services were likely to have been key components of the services content of Japanese exports: R\&D services, financial services, school education services and transportation services. Changing macroeconomic conditions after 1985 are likely to have resulted in shifts in the significance of these services.

\section{The services content of J apanese trade, 1985-95}

Table 4 illustrates the direct $\left(S_{t}^{D}\right)$, indirect $\left(S_{t}^{I D}\right)$ and net $-\left(S_{n x}=\left(S_{x}^{D}+S_{x}^{I D}\right)-\left(S_{m}^{D}+S_{m}^{I D}\right)\right)$ - services trade in Japan. Indirect services trade is defined as the services embodied in goods trade. These tables confirm that Japan's indirect services trade is larger than its direct services trade. Indirect exports and imports of services were twice as large as direct exports and imports throughout the period (except for imports in 1995). In 1990 net indirect service exports were large enough to cover the deficit in direct services trade. Therefore, total (direct plus indirect) services trade was in net surplus during the period, which is consistent with the results of Grubel (1988), Sazanami and Urata (1990) and Urata and Kiyota (2001).

At a sectoral level, net exports of services (direct plus indirect), $S_{n x}$, are relatively large in the wholesale, ocean transport and R\&D services sectors. Although wholesale and R\&D services trade grew rapidly between 1985 and 1995, the pattern of trade was quite different. Most of the net surplus in wholesale trade was from direct service trade, while all of the R\&D services trade was from indirect trade.

Table 5 reports the services content ratio for each service, $S_{n x} / S$, which is defined as net exports of direct and indirect services divided by domestic production. The services content 
ratio describes the intensity of that service in services trade. The larger the ratio, the larger the intensity.

The services content ratio for total services gradually decreased from 0.036 in 1985 , to 0.013 in 1990 and to 0.007 in 1995 . Since services production and value added both expanded over the period, this suggests that Japanese services lost international competitiveness.

Table 5 also indicates that Japan exports goods that are intensive in R\&D services. This might be because Japanese companies are highly technological. Ocean transport services had the top ranking, but air transport services were low. This could be because of the way transport services trade is defined. For instance, when Japanese people fly Japan Airlines to Australia, transportation trade does not occur, but when they fly Qantas, Australia exports transportation services to Japan. Therefore, care is needed in discussing trade in transportation services. ${ }^{7}$

Education services were ranked low until after 1990. Until recently Japanese companies provided in-house training to their graduate employees. The economic downturn has increased demand for employees who are already trained. The increased intensity of school education services has probably been the result of more school students completing school in order to go on to university. ${ }^{8}$

As expected, financial services declined in rank after 1985, from 15th to 31st in 1990 and to 44th in 1995. The declining significance of financial service in Japanese trade is a reflection of the poor performance of the financial sector since the burst of the asset market bubble in the late $1980 \mathrm{~s}$.

In sum the services content of trade is a reflection of what is happening in the domestic economy: competitive services are ranked highly while abundant but less competitive services are lower ranked. The services content analysis illustrates the international competitiveness of Japan's services.

\section{Alternative specifications of the model}

\section{Adjustment for trade vol umes}

One main problem with the model is that services trade will consistently be in surplus because the Japanese trade balance has consistently been in surplus. An adjustment can be made to compensate for the fact that Japan's exports are much larger than its imports. Following 
Pacific Economic Papers

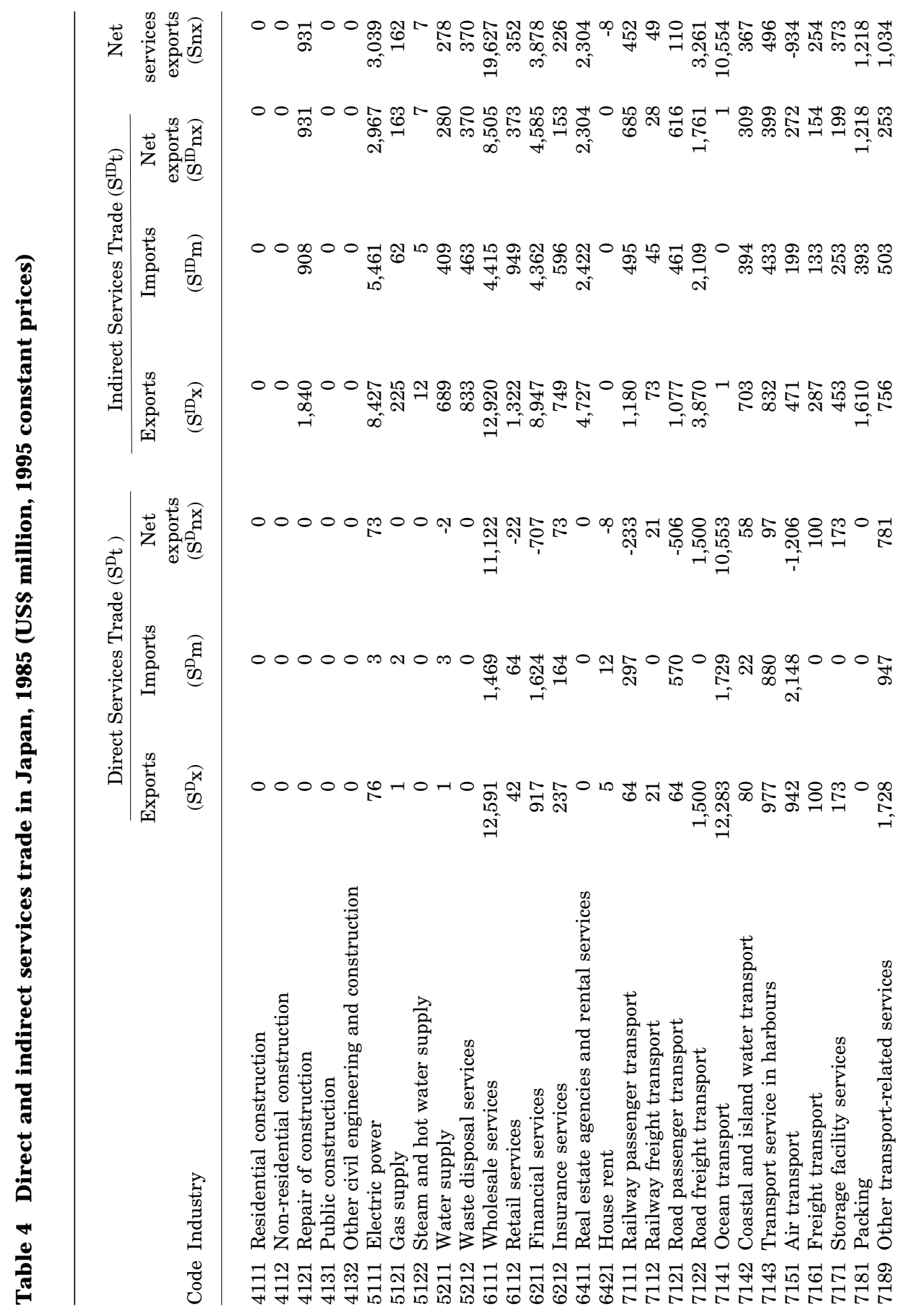




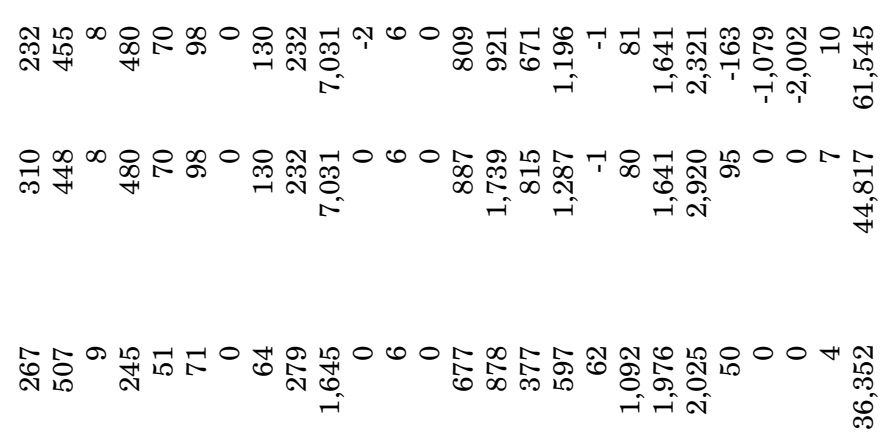

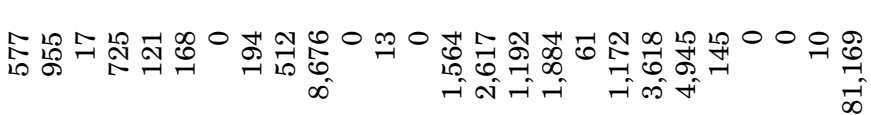

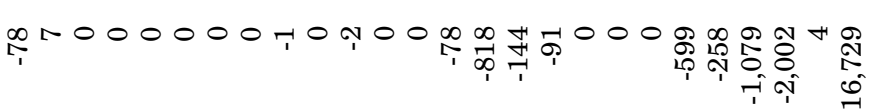

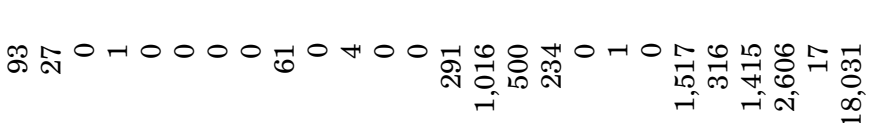

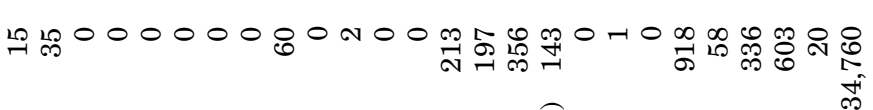

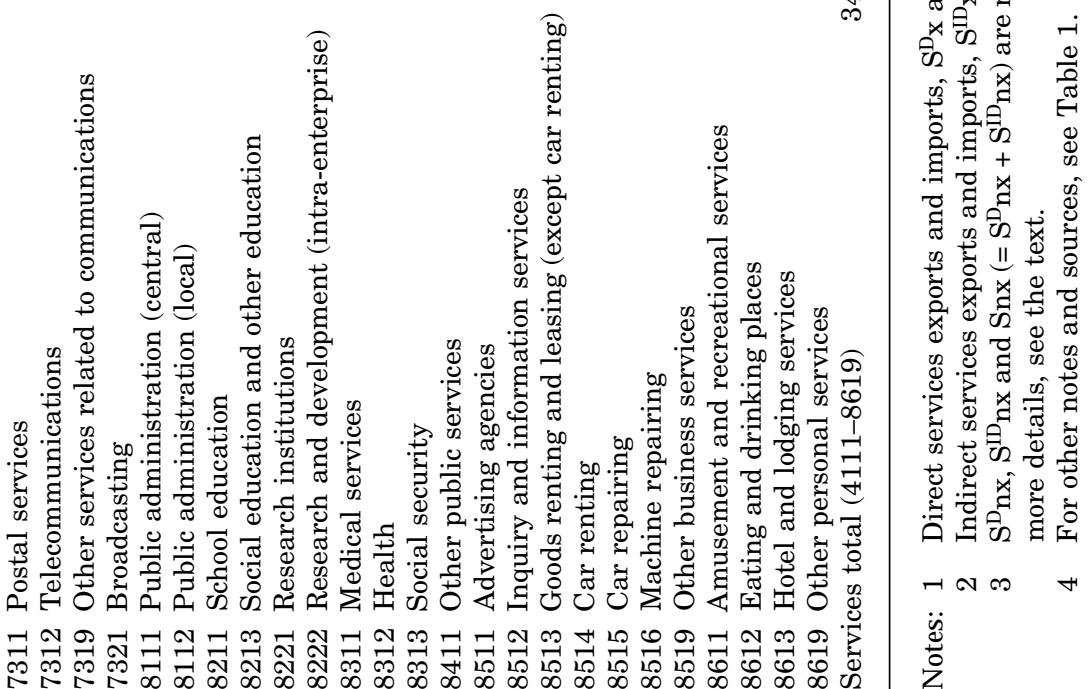


Pacific Economic Papers

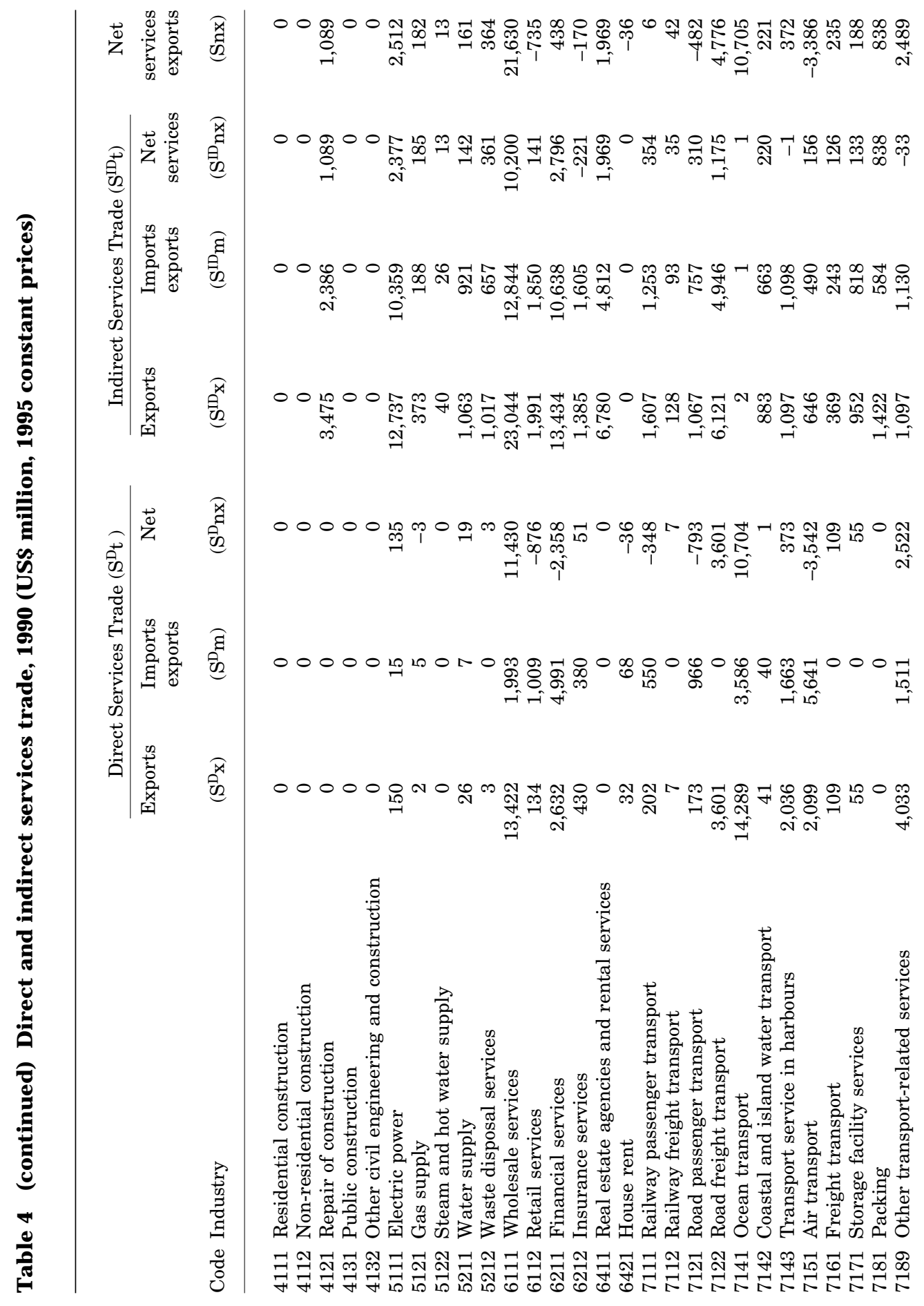


No. 320 O ctober 2001

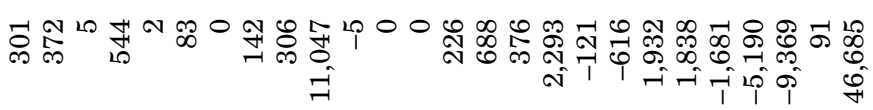

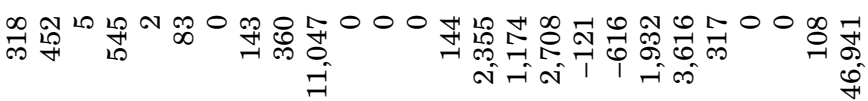

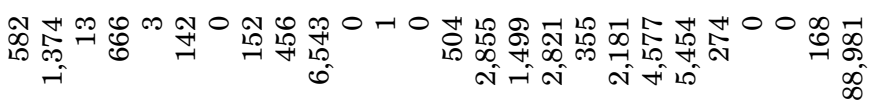

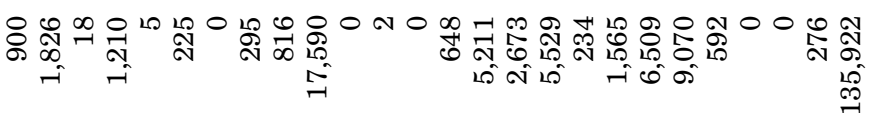

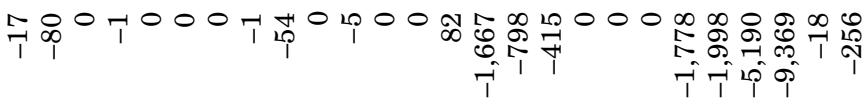

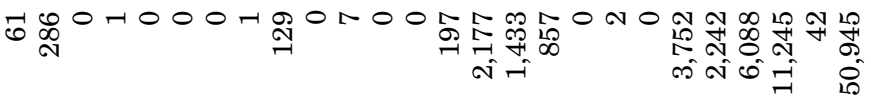

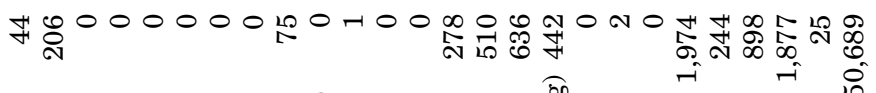

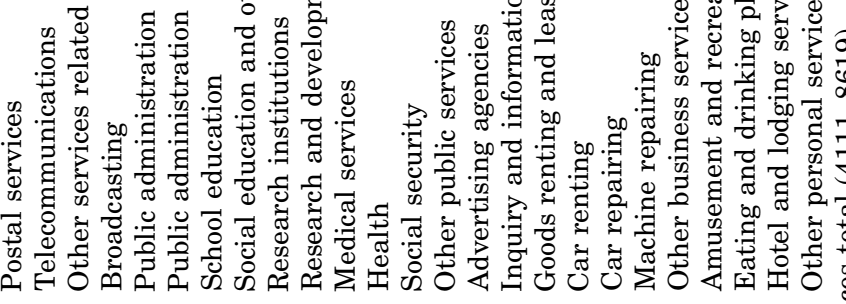

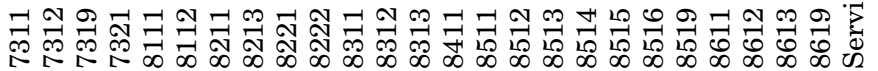


Pacific Economic Papers

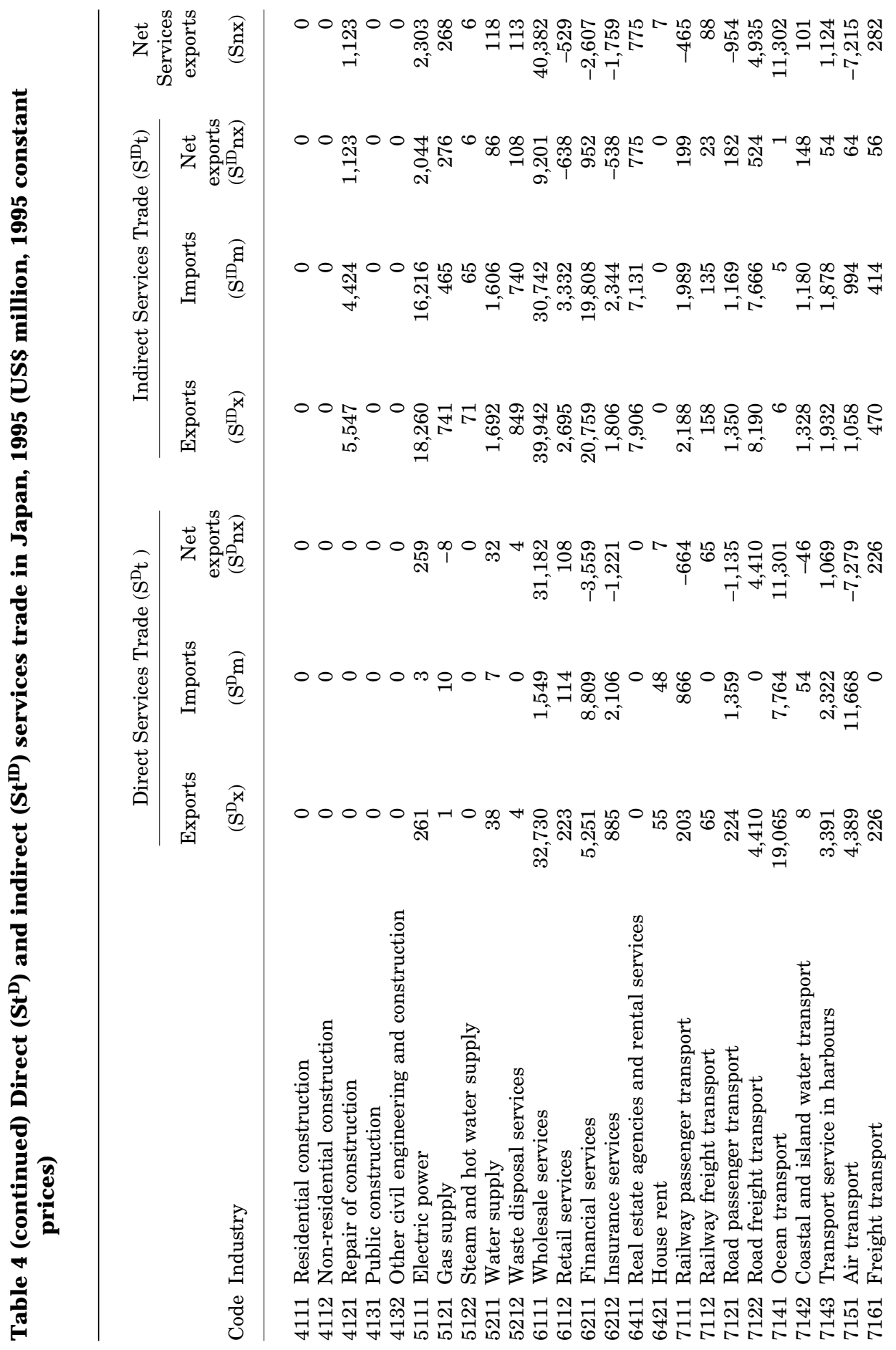




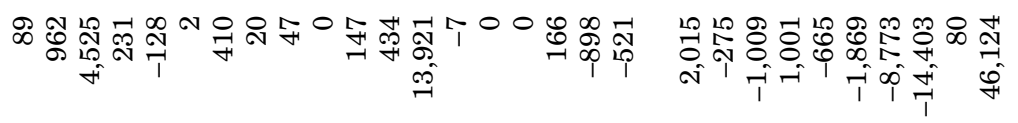

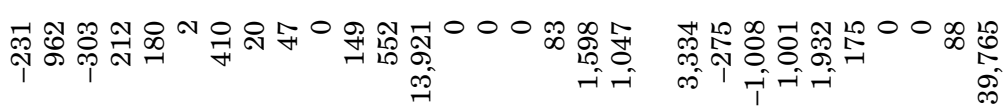

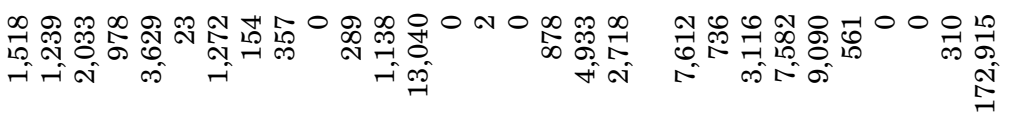

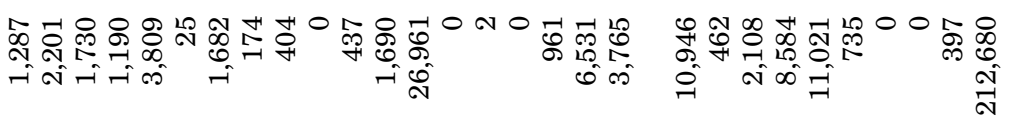

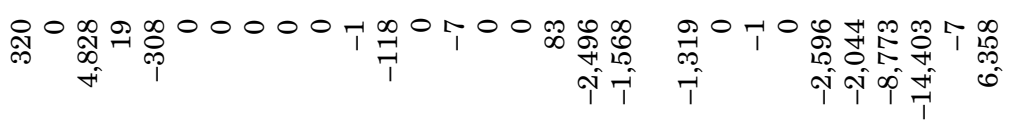

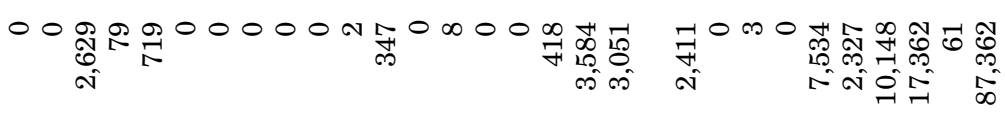

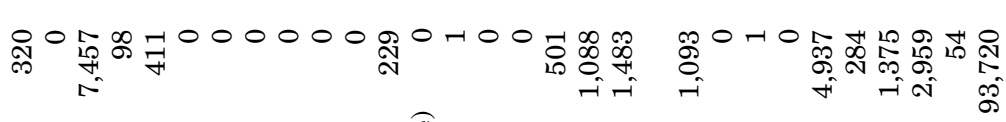

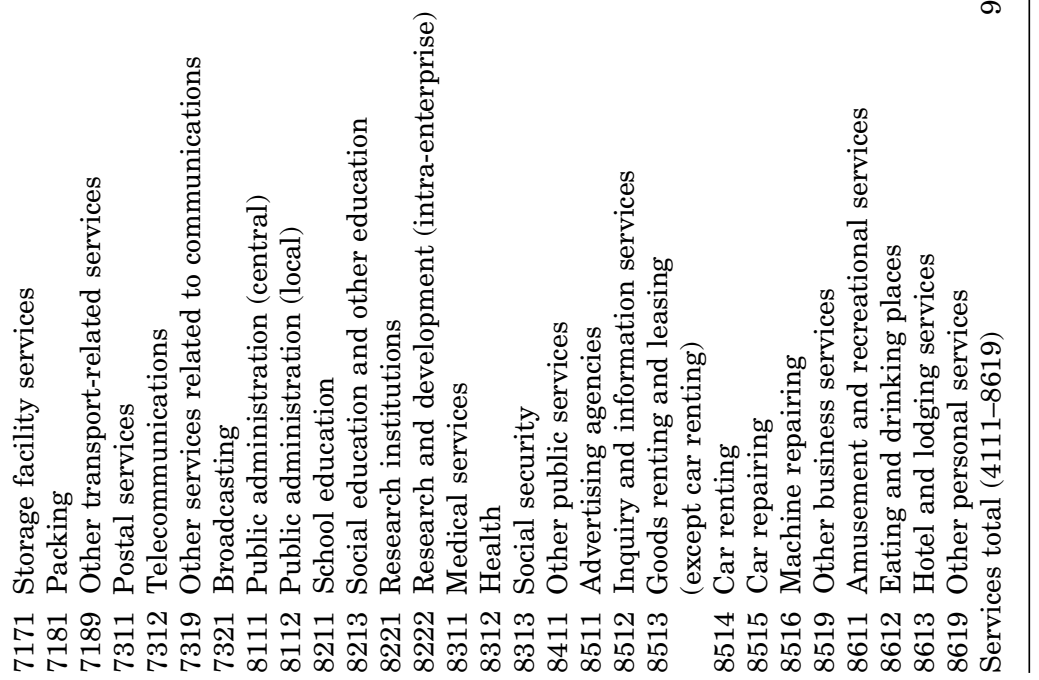




\section{Pacific Economic Papers}

Leontief (1953) and Urata and Kiyota (2001), the services content is computed by using approximately US $\$ 1$ million of exports and US $\$ 1$ million of imports. Table 6 provides the results of the analysis, giving useful information for a time-series comparison of patterns of trade and production. The service is more intensively traded if the ratio is greater than 1 and less intensively traded if it is smaller than 1 .

The results indicate that the services content of the US $\$ 1$ million of exports and US $\$ 1$ million of imports gradually decreased from 1985 to 1995 . The services content of exports fell from US $\$ 582,460$ in 1985 to US $\$ 513,913$ in 1995 . There was a similar decline in the services content of imports from US\$522,264 to US $\$ 485,450$. Since the decline in imports was more rapid than in exports, the services content ratio decreased between 1985 (1.115) and 1995 (1.059).

The rank of R\&D services remained high after the adjustment for trade volumes. The rank of R\&D services was in the top two between 1985 and 1995 in both Tables 5 and 6 . Financial services declined in rank, similar to the finding in Table 5, showing that the results for R\&D and financial services do not depend on the volume traded. On the other hand, transportation services ranked lower in Table 6 than in Table 5. In 1995 ocean transport services ranked 21st in contrast to its top rank in Table 5. This result suggests that the ranking is sensitive to the volume of goods trade. Table 6 shows school education services to be rising in rank more rapidly than in Table 5 .

\section{Adjustment for intermediate inputs}

Another problem with the original model is that it may be overestimating the output of services because the service content is defined as domestic production (sales) caused by trade, which includes intermediate inputs. Some of these inputs will be goods consumed by service producers. The larger the cost of the intermediate inputs, the larger the sales of services.

One possible remedy would be to focus on value added rather than production by multiplying the services content of trade in Table 4 by the value-added ratio (value added divided by domestic production in Table 1). However, this remedy is meaningless since equation (4) suggests that the weight for value added cancels itself out from the numerator and the denominator $\left(\left(v_{x i}^{h} S_{x i}^{h}-v_{i}^{h} S_{m i}^{h}\right) / v_{i}^{h} S_{i}^{h}=\left(S_{x i}^{h}-S_{m i}^{h}\right) / S_{i}^{h}\right)$ because it is assumed that the value added of exports of good $i$ is the same as that of imports of good $i$. In order to compute the value added of imports correctly, value-added data for all imported goods would be needed. This extremely difficult task is beyond the scope of this paper and remains on the author's future research agenda. 


\section{Conclusion}

This paper reveals that the services content ratio is higher for R\&D services than for other services during the period 1985 to 1995 . The rank of school education services gradually increased over the period while the rank of financial services decreased. These results indicate that Japan increased its exports of technology-intensive products throughout the period, moving away from goods intensive in financial services to those intensive in educational services. The decline in the content of financial services, together with the fact that Japanese banking and insurance companies are rapidly exiting from abroad, contests to the decline in the international competitiveness of the financial sector. Structural reform in some services sectors is still underway and more reform is needed, especially in the financial sector.

A few words of caution are needed. The use of the input-output table in estimating the services content of exports may be problematic. Production technologies used in exports tend to be different from those used in the production of goods sold in the domestic market, but the table does not distinguish between them. This is likely to be a particular problem in the cases of transportation and distribution services. Export production uses fewer transportation services, retail services or wholesale services than domestic production does.

The services content of imports analysed here is the content used in the production of import-competing goods rather than imports. It would be difficult to calculate the services contents of imports as this would require the input-output tables of all exporting countries. However, this does not cause a problem if the production technologies, or input-output relations, are identical between countries, as is assumed in the HOV model.

The results for imports need to be carefully interpreted. Japan is a highly industrialised country, so the value-added ratio (value added divided by domestic production) for exports is likely to be higher than that for imports, implying an underestimation of the services content of net exports. The remedy to this problem is again the analysis of all exporting countries' inputoutput tables or of the information on value added by country and commodity (industry).

The analysis in this paper could be extended in at least two directions. An international comparison would be very interesting, as the difference in $R \& D$ services content between industrialised and developing countries would shed some light on technology transfer. Such a comparison would also contribute to the construction of world services trade data. Second, an analysis of other types of services, such as commercial presence, could also be done. This paper focuses only on direct and indirect services trade, but consumption abroad and commercial presence (through foreign direct investment) are likely to be other important modes of services 
Pacific Economic Papers

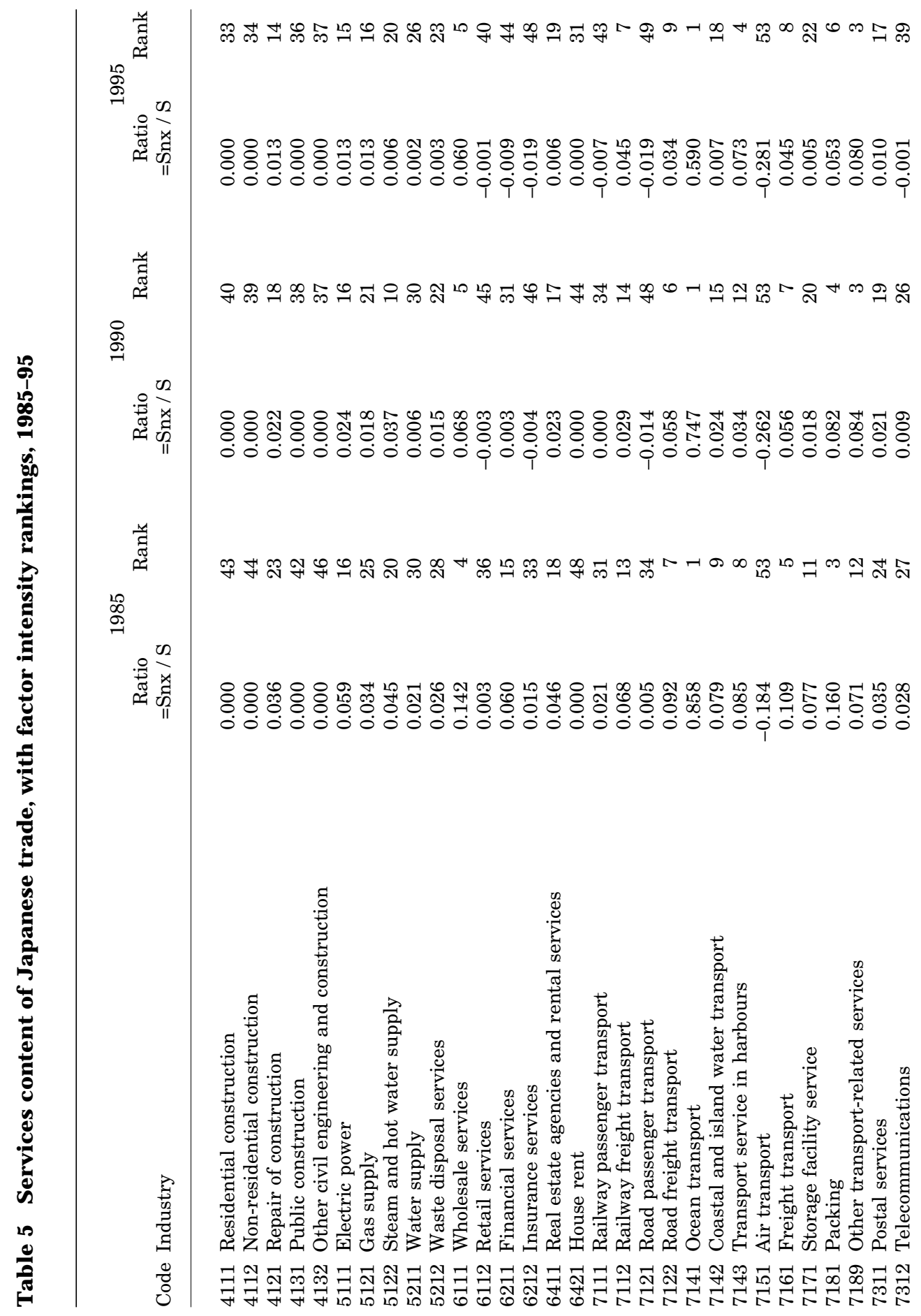


No. 320 O ctober 2001

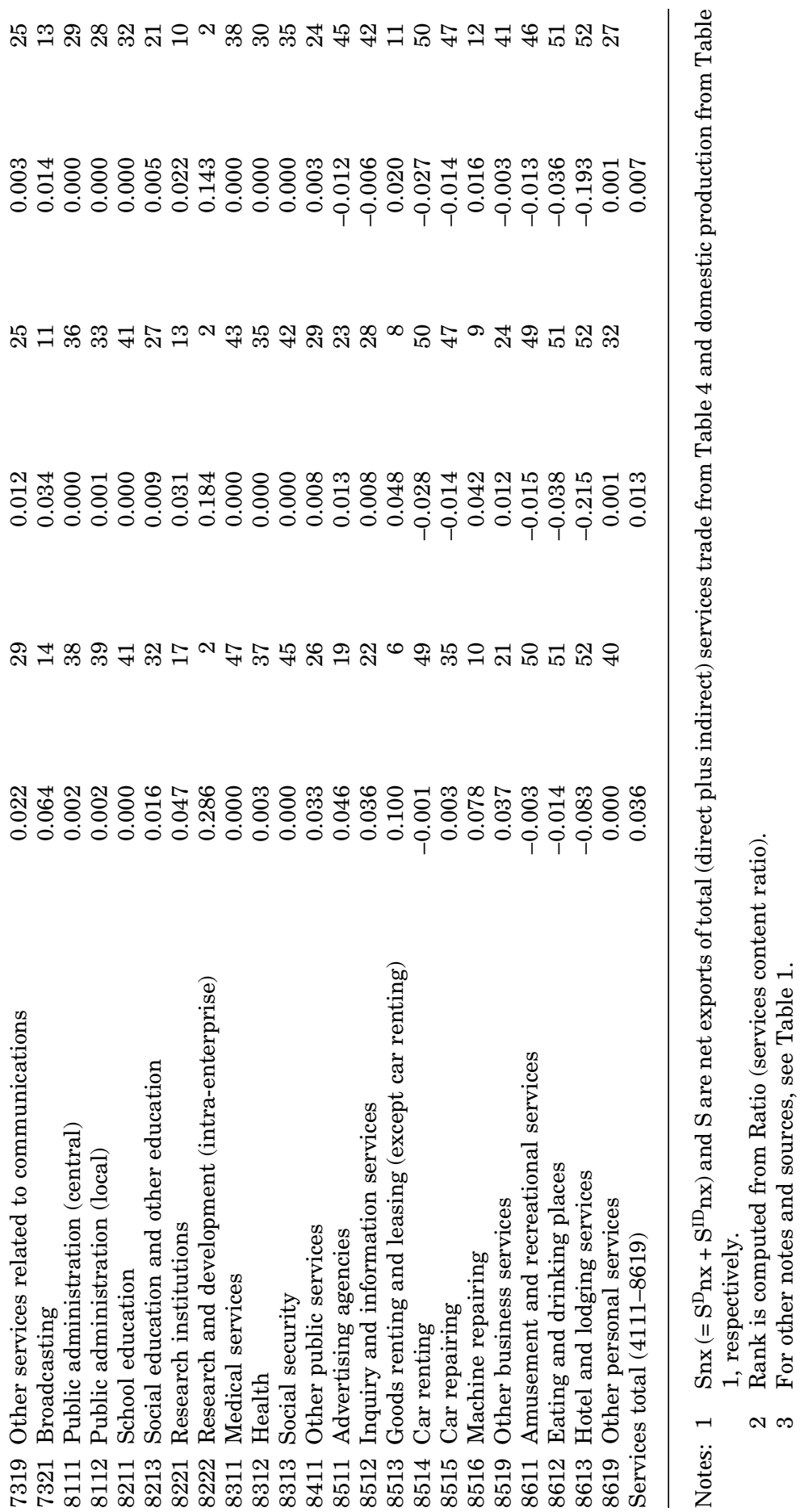


Pacific Economic Papers

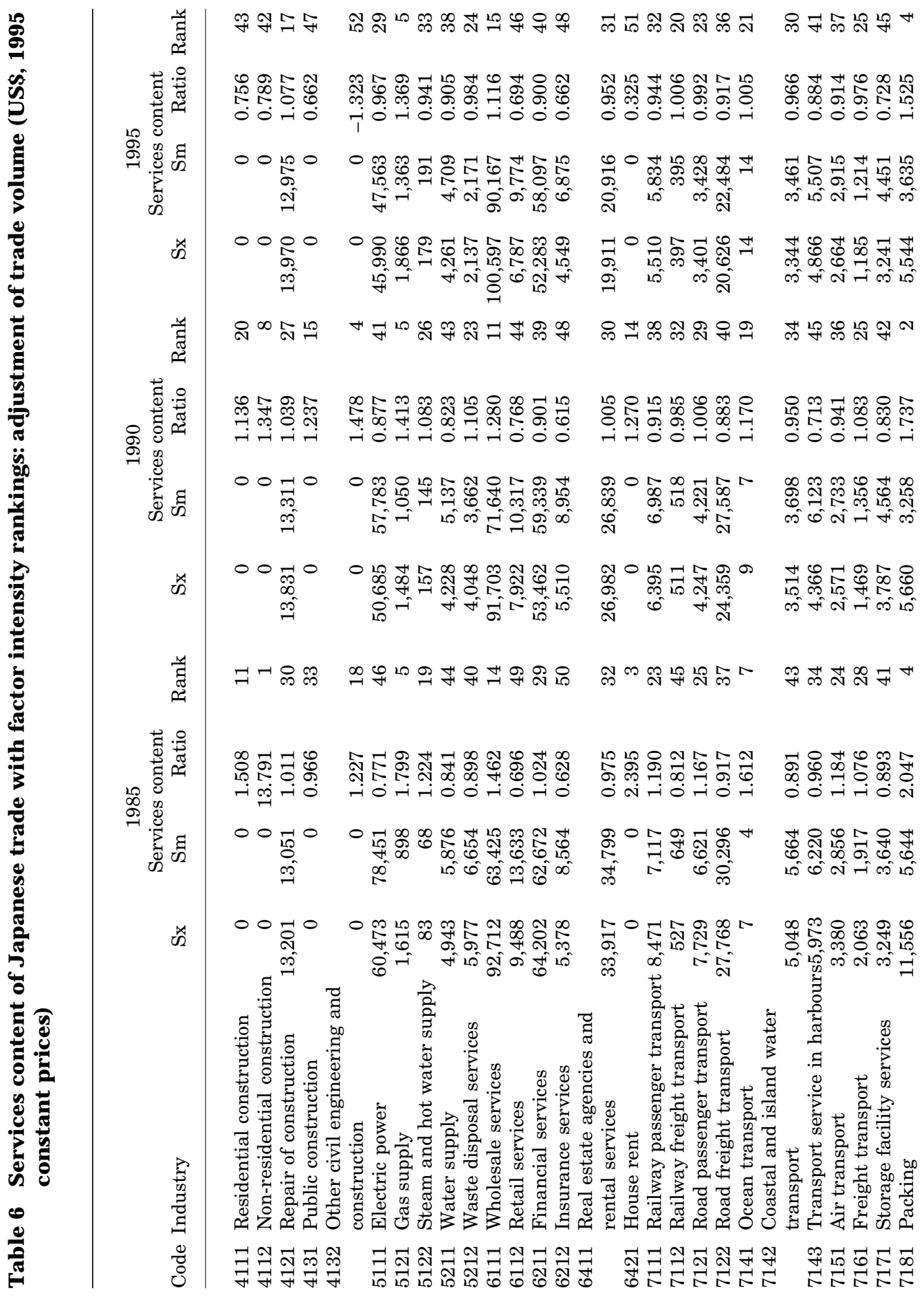


我年

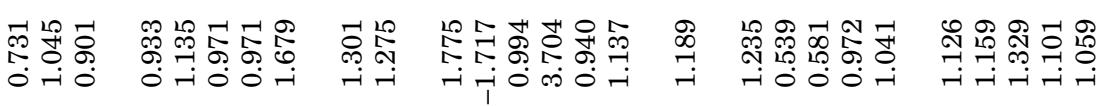

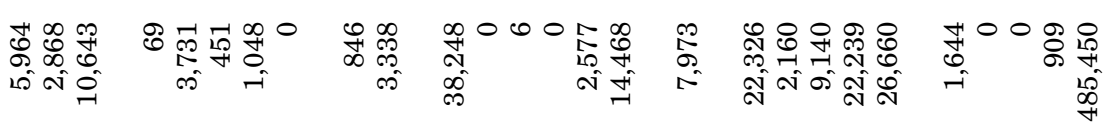

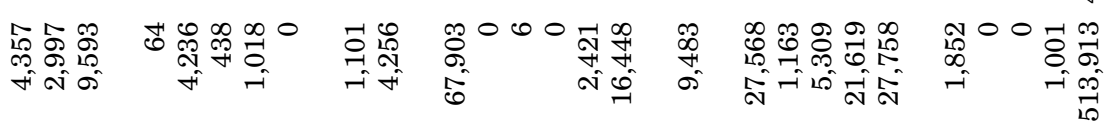

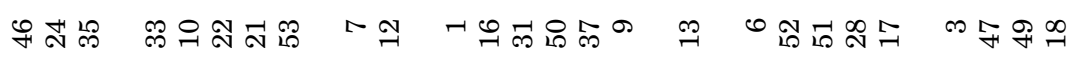

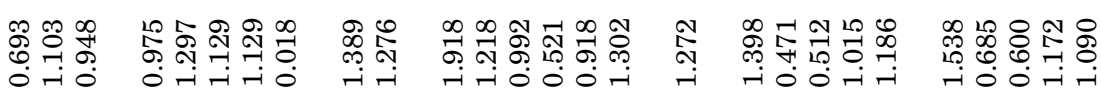

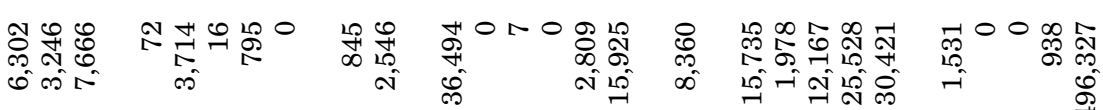

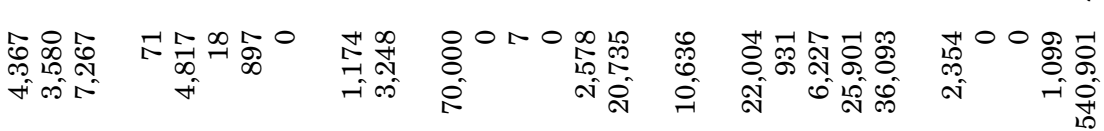

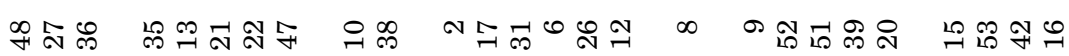

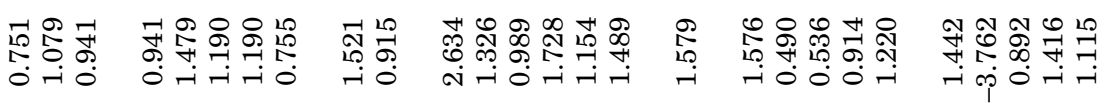

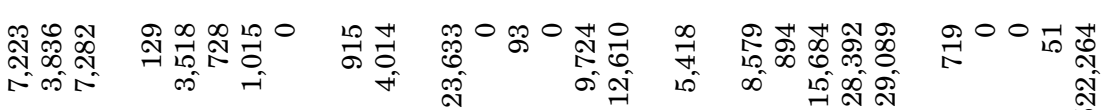

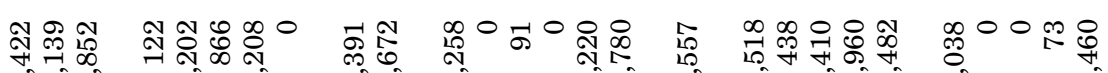

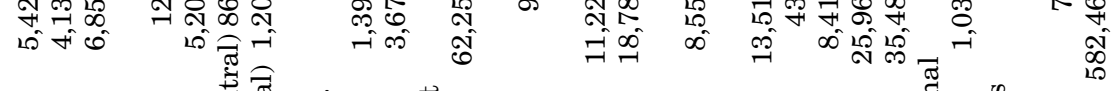

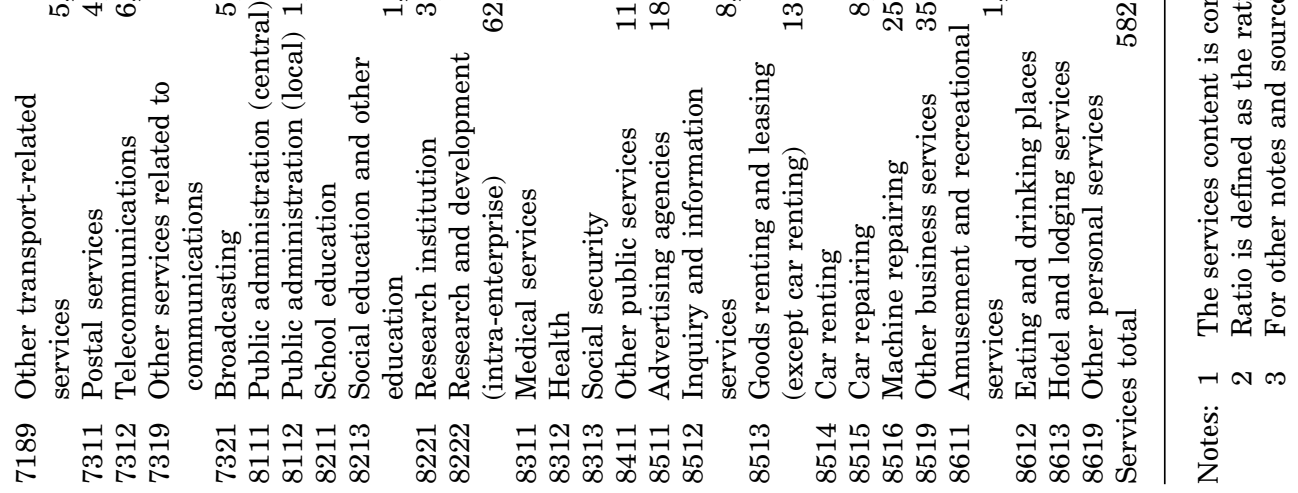




\section{Pacific Economic Papers}

trade. The input-output table used in this paper cannot distinguish between foreign and Japanese affiliates in Japan, but such transactions are important as the activities of multinational enterprises have expanded. Data availability and quality will be barriers to extending this work.

\section{Notes}

* I am grateful for the comments and suggestions of Keith Maskus, Shujiro Urata, Fukunari Kimura, Masahiko Shimizu, Kazusuke Tsujimura, Peter Drysdale, Masayuki Morikawa, Kozo Miyagawa and two anonymous referees. However, the opinions expressed in this paper are entirely mine.

1 See, for example, Dick and Dicke (1979), Sapir and Lutz (1981), Sazanami and Urata (1990) and Urata and Kiyota (2001).

2 The importance of factor and intermediate services trade is also stressed by Markusen (1989) and Melvin (1989).

3 For the derivation of equation (2), see the appendix.

4 For more on rank proposition see, for instance, Bowen, Leamer and Sveikauskas (1987) and Kohler (1991).

5 The GDP growth rate is computed using GDP market prices (in 1995 US dollars) from World Bank (2000).

$6 \quad$ Unless otherwise noted, the discussions in this section refer to the data for 1995.

$7 \quad$ This point was covered in Snape (2001).

8 According to the Minister's Secretariat of the Ministry of Education (2001), the number of Masters and Doctoral graduates in Japan rose from 18,872 in 1980 to 49,700 in 1995.

\section{References}

Bayoumi, Tamim, David T. Coe and Elhanan Helpman (1999) 'R\&D spillovers and global growth', J ournal of I nternational E conomics 47(2): 399-429.

Bowen, Harry P., Edward E. Leamer and Leo Sveikauskas (1987) 'Multicountry, multifactor tests of the factor abundance theory', American E conomic Review 77(5): 791-809.

Coe, David T. and Elhanan Helpman (1995) 'International R\&D spillovers', European E conomic Review 39(6): 859-89.

Coe, David T. and Elhanan Helpman and Alexander W. Hoffmaister (1997) 'North-South R\&D Spillovers', E conomic J ournal 134-49. 
Deardorff, Alan V. (1985) 'Comparative advantage and international trade and investment in services', in Robert M. Stern (eds) Trade and Investment in Services: Canada/ US Perspectives, Toronto: Ontario Economics Council.

Dick, Rolf and Hugo Dicke (1979) 'Patterns of trade in knowledge', in Herbert Giersch (eds) International Economic Devel opment and ResourceTransfer: Workshop 1978, Tubingen, Mohr, Keil: Institut fur Weltwirtschaft.

Grubel, Herbert G. (1988) 'Direct and embodied trade in services', in Chung H. Lee and Naya Seiji (eds) Trade and I nvestment in Services, Boulder: Westview Press.

International Monetary Fund (2001) International Financial Statistics on CD-ROM, Washington DC: IMF.

Kimura, Fukunari and Hirohisa Kohama (1995) Empirical International Economics, Tokyo: Nihon Hyoron Sya (in Japanese)

Kohler, Wilhelm (1991) 'How robust are sign and rank order tests of the Heckscher-Ohlin Vanek Theorem', Oxford E conomic Papers 43(1): 158-71.

Leamer, Edward E. (1980) 'The Leontief Paradox, reconsidered', J ournal of Political E conomy, 88(3): 495-503.

Leontief, Wassily W. (1953) 'Domestic production and foreign trade: the American capital prostitution re-examined', Proceeding of the American Philosophical Society 97(4): 332-49. Reprinted in Wassily Leontief (1986) Input-Output Economics, 2nd edition, Oxford: Oxford University Press.

Management and Coordination Agency (2000) Input-Output Table, 1985, 1990, 1995.

Markusen, James R. (1989) 'Trade in producer services and in other specialized intermediate inputs', American Economic Review 79(1): 8595.

Maskus, Keith E. (1985) 'A test of the Heckscher-Ohlin-Vanek theorem', J ournal of I nternational Economics 19(3/4): 201-2.

Melvin, James R. (1989) ‘Trade in producer services: a Heckscher-Ohlin approach', J ournal of Political Economy 97(5): 1180-96.

Minister's Secretariat, Ministry of Education (2001) TheSchool Basic Survey, 2001.

Sapir, Andre and Ernst Lutz (1981) 'Trade in services: economic determinants and development-related issues', World Bank Staff Working Papers No. 480, Washington DC: World Bank.

Sazanami, Yoko and Shujiro Urata (1990) Sabis boueki: riron, jissyo, kadai (Trade in services: theory, empirics and future agenda), Tokyo: Toyokeizai (in Japanese)

Snape, Richard (2001) 'Comments on Shujiro Urata and Kozo Kiyota: "Service trade in East Asia", in Takatoshi Ito and Anne O. Krueger (eds) Services Trade in the Asia-Pacific Region, NBER East Asia Seminar on Economics, Vol. 11, Cambridge: University of Chicago Press, forthcoming.

Toyokeizai (2001) Kaigai shinsyutsu kigyou souran (Directory of Japanese Subsidiaries Abroad), Tokyo: Toyokeizai (in Japanese).

Tucker, Ken and Mark Sundberg (1988) International Tradein Services, London: Routledge.

Urata, Shujiro (1983) 'Factor inputs and Japanese manufacturing trade structure', Review of E conomics and Statistics 65(4): 678-84.

Urata, Shujiro and Kozo Kiyota (2001) 'Service trade in East Asia', in Takatoshi Ito and Anne O. Krueger (eds) Services Tradein the Asia-Pacific Region, NBER East Asia Seminar on Economics, Vol. 11, Cambridge: University of Chicago Press, forthcoming.

World Bank (2000) World Devel opment I ndicators on CD-ROM, Washington DC: World Bank. 


\section{Appendix: Derivation of equation (2)}

In deriving equation (2), the country index $\mathrm{h}$ is dropped to simplify the analysis, without losing generality. The total (direct plus indirect) services content is defined as:

$$
\hat{\mathbf{S}}^{-1} \mathbf{S}_{t}=\hat{\mathbf{S}}^{-1}\left[\mathbf{S}_{t}^{D}+\mathbf{S}_{t}^{I D}\right]
$$

The direct services content is the direct trade in services divided by the domestic output of services:

$$
\hat{\mathbf{S}}^{-1} \hat{\mathbf{S}}_{t}^{D}=\hat{\mathbf{S}}^{-1}[\alpha \mathbf{T}]
$$

where $\alpha$ is a diagonal matrix of $\alpha$, which takes the value of 1 if $i \geq k+1$ and 0 if $i \leq k$. Since the indirect services are defined as the services embodied in goods trade, it is formalised as:

$$
\hat{\mathbf{S}}^{-1} \mathbf{S}_{t}^{I D}=\hat{\mathbf{S}}^{-1}\left[\hat{\alpha}(\mathrm{I}-\mathrm{A})^{-1} \cdot \hat{\beta} \Gamma\right]=\hat{\mathbf{S}}^{-1}[\hat{\alpha} \mathrm{B} \cdot \mathrm{T}]
$$

where $\hat{\beta}$ is a diagonal matrix of $\beta$, which takes the value of 1 if $\mathrm{i} \geq \mathrm{k}$ and 0 if $\mathrm{i} \leq \mathrm{k}+1$. From these equations, the total (direct plus indirect) services content of exports and imports are, respectively:

$$
\left(\hat{\mathbf{S}}^{h}\right)^{-1}\left[\mathbf{S}_{x}^{h}-\mathbf{S}_{m}^{h}\right]=\left(\hat{\mathbf{S}}^{h}\right)^{-1}\left[\left(\hat{\alpha} \mathbf{E} \mathbf{X}^{h}=\hat{\alpha} \mathbf{B}^{h} \cdot \hat{\beta} \mathbf{E} \mathbf{X}^{h}\right)-\left(\hat{\alpha} \mathbf{I} \mathbf{M}^{h}+\hat{\alpha} \mathbf{B}^{h} \cdot \hat{\beta} \mathbf{I} \mathbf{M}^{h}\right)\right]
$$

which corresponds to equation (2). 


\section{Previous Pacific Economic Papers}

319 Changes in the Japanese food sector

Ray Trewin et al., September 2001

318 The changing economic performance and political significance of Japan's agricultural cooperatives

Yoshihisa Godo, August 2001

317 Bank and corporate restructuring in crisis-affected East Asia: from systemic collapse to reconstruction

Masahiro Kawai, July 2001

316 Hot and spicy: ups and downs on the price floor and ceiling at Japanese supermarkets

Kenn Ariga, June 2001

315 China's admittance to the WTO and industrial structural adjustment in the world economy Christopher Findlay, May 2001

314 'Japan Inc.' in the agricultural sector: reform or regression? Aurelia George Mulgan, April 2001

313 Encouraging 'democracy' in a Cold War climate: the dual-platform policy approach of Evatt and Labor toward the allied occupation

Christine de Matos, March 2001

312 Managing capital flows: a distortions approach

Dominic Wilson, February 2001

311 Old issues in new regionalism

Christopher Findlay, January 2001

310 Trade conflicts between Japan and the United States over market access: the case of automobiles and automotive parts

Masao Satake, December 2000

309 Subregional trading arrangements among APEC economies: managing diversity in the Asia Pacific

Andrew Elek, November 2000

308 Weathering the Asian crisis: the role of China

Yongzheng Yang and Rod Tyers, October 2000

307 The internationalisation of the yen: essential issues overlooked

Tetsuji Murase, September 2000 
306 Japan's local governance at the crossroads: the third wave of reform Purnendra Jain, August 2000

305 Some key issues for the East Asian food sector M. Honma, R. Trewin, M. Bosworth, R. Stringer and Y. Godo, July 2000 (special volume)

304 Food embargoes against China: their likelihood and potential consequences Yongzheng Yang, June 2000

303 Foreign direct investment and intra-industry trade - the case of the United States Tina Yiping Chen, May 2000

302 Implications of recent Japanese legal reforms

Leon Wolff, Veronica Taylor and Akiyoshi Horiuchi, April 2000 (special volume)

301 Toward reform and transparency in Japanese policymaking processes J.A.A. Stockwin, Jennifer Amyx and Gregory Noble, March 2000 (special volume)

300 A way forward for Japanese agriculture?

Masayoshi Homna, Ray Trewin, Jennifer Amyx and Allan Rae, February 2000 (special volume)

299 Japanese foreign direct investment in the world economy 1951-1997 Roger Farrell, January 2000

298 The genesis of APEC: Australian-Japanese political initiatives Takashi Terada, December 1999

297 Is shutting Krugman's 'liquidity trap' the answer to Japan's problems? Dominic Wilson, November 1999

296 Japanese government-business collaboration and the operations of Japanese corporations in Asia: A telecommunications case Hidetaka Yoshimatsu, October 1999

295 Free trade champion? Australian views of the US crusade against Japan Julia Lowell, September 1999

294 Governance and Australian financial institutions Kevin Davis, August 1999

293 The changing climate for foreign direct investment into Japan Peter Drysdale, Ray Trewin, Toshi Naito and Dominic Wilson, July 1999 
292 The Japanese origins of PAFTAD: The beginning of an Asian Pacific economic community

Takashi Terada, June 1999

291 Not just a question of multilateral free trade: Australia's bilateral trade liberalisation agenda towards Japan

J amie Anderson, May 1999

290 Perspectives on Japanese investment, employment and management in Australia Roger Farrell and Peter Drysdale, April 1999

289 Predicting banking crises: Japan's financial crisis in international comparison Michael Hutchinson and Kathleen McDill, March 1999

288 Japan's financial reform Volume I

Hugh Patrick, Takatoshi Ito, February 1999

287 International trade and environmental policy: how effective is 'eco-dumping'? Xinpeng Xu, January 1999

286 Open regionalism going global: APEC and the new transatlantic economic partnership Andrew Elek, December 1998

285 Realism and postwar US trade policy J ohn Kunke, November 1998

284 Attracting FDI: Australian government investment promotion in Japan, 1983-96 J amie Anderson, October 1998

283 The Multi-function polis 1987-97: an international failure or innovative local project?

Paul Parker, September 1998

282 Organisation, motivations and case studies of Japanese direct investment in real estate 1985-94

Roger Farrell, August 1998

281 Japan's approach to Asia Pacific economic cooperation

Peter Drysdale, July 1998

280 The politics of telecommunications reform in Japan Hidetaka Yoshimatsu, June 1998

279 Sustainability of growth in the Korean manufacturing sector Chang-Soo Lee, May 1998

278 Export performance of environmentally sensitive goods: a global perspective Xinpeng Xu, April 1998 
277 Modelling manufactured exports: evidence for Asian newly industrialising economies

Francis In, Pasquale Sgro and J ai-Hyung Yoon, March 1998

276 Laos in the ASEAN free trade area: trade, revenue and investment implications J ayant Menon, February 1998

275 Globalisation

Heinz Arndt, January 1998

274 The WTO and APEC: What role for China?

Stuart Harris, December 1997

273 The APEC air transport schedule

Christopher Findlay, November 1997

272 Japanese foreign direct investment in real estate 1985-1994

Roger Farrell, October 1997

271 China and East Asia trade policy volume 4: Trade reform and liberalisation in China

Yang Shengming, Zhong Chuanshui, Yongzheng Yang, Feng Lei,

Annual subscription rate for twelve issues:

Individuals A $\$ 65.00$

Institutions A $\$ 110.00$

Cost for single issues:

$\mathrm{A} \$ 15.00$

$\mathrm{A} \$ 10.00$ (Students)

No postage required within Australia

Available from: Publications Department

Australia-Japan Research Centre

Asia Pacific School of Economics and Management

The Australian National University

Canberra ACT 0200, Australia

Facsimile: (61 2) 61250767

Telephone: (61 2) 61253780

E-mail: ajrc@anu.edu.au

URL: http://ajrcnet.anu.edu.au/ 